\title{
Rhizosphere Effect of Kharif Crops on Phosphatases and Dehydrogenase Activities in a Typic Haplustert
}

\author{
M. L. Dotaniya - S. K. Kushwah • S. Rajendiran • M. V. Coumar • \\ S. Kundu $\cdot$ A. Subba Rao
}

Received: 8 March 2013/Revised: 24 July 2013 / Accepted: 22 October 2013/Published online: 12 March 2014

(C) The Author(s) 2014. This article is published with open access at Springerlink.com

\begin{abstract}
In recent years phosphorus crisis is emerging at global level, every country in the world searching for alternative sources and management options for increasing its supply and use efficiency. Increasing cost of cultivation due to phosphatic fertilizers, attracting our mind towards it. In this experiment it was focused on effect of major kharif crops (maize, soybean, sorghum, pearl millet, finger millet and rice) on phosphatases and dehydrogenase activities in soil at different crop growth periods (30, 50, 75, 90 days after sowing and at crop harvest). Acid phosphatase activity varied crop wise and also at different crop growth periods. The maximum acid phosphatase activities were observed at $75 \mathrm{DAT}$ in rice $(0.206 \mathrm{mg} \mathrm{PNP} / \mathrm{g} \mathrm{h}), 90 \mathrm{DAS}$ in sorghum (0.194 mg PNP/g h) and pearl millet $(0.201 \mathrm{mg}$ $\mathrm{PNP} / \mathrm{g} \mathrm{h}), 50 \mathrm{DAS}$ in soybean $(0.127 \mathrm{mg} \mathrm{PNP} / \mathrm{g} \mathrm{h})$, and 30 DAS in maize (0.154 $\mathrm{mg}$ PNP/g h) and, 50 DAS as well as 75 DAS in finger millet $(0.180 \mathrm{mg} \mathrm{PNP} / \mathrm{g} \mathrm{h})$, respectively. But alkaline phosphatase activities were maximum at 75 days after sowing in all the crops i.e. sorghum (0.533 mg PNP/g h), soybean $(0.465 \mathrm{mg} \mathrm{PNP} / \mathrm{g} \mathrm{h})$, rice $(0.440 \mathrm{mg} \mathrm{PNP} / \mathrm{g} \mathrm{h})$, maize $(0.538 \mathrm{mg} \mathrm{PNP} / \mathrm{g} \mathrm{h})$, pearl millet $(0.546 \mathrm{mg} \mathrm{PNP} / \mathrm{g} \mathrm{h})$ and finger millet $(0.530 \mathrm{mg}$ $\mathrm{PNP} / \mathrm{g} \mathrm{h}$ ), respectively. The dehydrogenase activities were also higher in 75 days after sowing in all the crops. These
\end{abstract}

\footnotetext{
M. L. Dotaniya ( $₫)$ - S. Rajendiran · M. V. Coumar ·

S. Kundu - A. Subba Rao

Indian Institute of Soil Science, Nabibagh, Berasia Road, Bhopal 462 038, India

e-mail: mohan30682@gmail.com

S. K. Kushwah

Jawaharlal Nehru Krishi Vishwa Vidyalaya, Jabalpur, India
}

enzyme activities associated with higher availability and uptake of phosphorus.

Keywords Acid phosphatase activity .

Alkaline phosphatase activity · Dehydrogenase activity

\section{Introduction}

Phosphorus $(\mathrm{P})$ is an important plant nutrient for crop growth and crop yield [1, 2]. It maintains biochemical, metabolic functions in plants; maintains soil fertility and soil health [3]. But lower phosphorus use efficiency limits crop yield and economic return [4]. Phosphorus fertilizers are totally imported in India and indigenous rock phosphate having low $\mathrm{P}$ concentration, increasing crop production cost. Plants exudate various type organic substances [5], which convert immobilize P into more plant available P [6]. Different phosphatases enzyme activities speed up the conversion process of immobile $\mathrm{P}$ to plant available $\mathrm{P}$ in soil solution, and indirectly enhance plant $\mathrm{P}$ uptake [7]. In rhizosphere region many microorganisms play a crucial role to enhance enzyme activities and $\mathrm{P}$ solubilization process. But it varies accordingly crop wise, species wise and under different crop cultivation practices [8]. Bacteria are more effective in phosphorus solubilization than fungi [9]. Among the whole microbial population in soil, phosphate solubilizing bacteria constitute $1-50 \%$, while phosphorus solubilizing fungi are only $0.1-0.5 \%$ in P solubilization potential [10]. Hence the effect of different crops on phosphatase enzyme activities and dehydrogenase activity (DHA) should be studied and understood. Keeping all the above in mind, the pot culture experiment was conducted to understand the rhizosphere effect of maize, soybean, sorghum, pearl millet, finger millet and rice on these enzyme activities. 


\section{Materials and Methods}

A pot culture experiment was conducted at Indian Institute of Soil Science (IISS), Bhopal, India during kharif season of 2011. Geographically, Bhopal is situated at $23^{\circ} 18^{\prime} \mathrm{N}$, $77^{\circ} 24^{\prime} \mathrm{E}$ and $485 \mathrm{~m}$ above mean sea level. It has semi-arid and sub-tropical dry summer and the cold winter climate with a mean annual air temperature of $25^{\circ} \mathrm{C}$ and annual rainfall of $1,208 \mathrm{~mm}$. Soil for the pot experiment was collected from the field of IISS, Bhopal. The collected soil was air dried and ground, and passed through a $2 \mathrm{~mm}$ sieve. The experimental soil belongs to Vertisols i.e. Hypothermic family of Typic Haplusterts popularly known as "black cotton soil". The soil had the following properties : texture clay loam; $\mathrm{pH}(1: 2.5) 8.06 ; \mathrm{EC}\left(\mathrm{dSm}^{-1}\right)$ 0.57; organic carbon $0.44 \%$; available $\mathrm{N} 115 \mathrm{~kg} \mathrm{ha}^{-1}$; available P $7.53 \mathrm{~kg} \mathrm{ha}^{-1}$, available $\mathrm{K} 185 \mathrm{~kg} \mathrm{ha}^{-1}$ and available $\mathrm{S}$ $9.1 \mathrm{~kg} \mathrm{ha}^{-1}$. The processed soil was filled in 90 plastic pots @ $10 \mathrm{~kg} /$ pot. In this experiment six crops were grown viz. maize, soybean, sorghum, pearl millet, finger millet and rice; the details of crop varieties and their characteristic features were depicted in Table 1. The crops were grown and rice seedlings were transplanted and replicated thrice. Recommended dose of $\mathrm{N}, \mathrm{P}_{2} \mathrm{O}_{5}$ and $\mathrm{K}_{2} \mathrm{O}(\mathrm{kg} / \mathrm{ha})$ were applied i.e. 100:60:60 for sorghum, rice, maize and pearl millet; 30:60:40 for soybean and 60:40:40 for finger millet through urea, diammonium phosphate and muriate of potash. Half dose $(50 \%)$ of $\mathrm{N}$ and full doses of $\mathrm{P}_{2} \mathrm{O}_{5}$ and $\mathrm{K}_{2} \mathrm{O}$ were applied as basal at the time of sowing in all the crops but in soybean all the nutrients were applied at the time of sowing. The remaining $\mathrm{N}$ was applied as two equal splits at 30 and 60 DAS. Zinc sulphate was applied @ $10 \mathrm{~kg} / \mathrm{ha}$ for rice and $7 \mathrm{~kg} / \mathrm{ha}$ other crops at the time of sowing. Soil samples were collected during the crop growth period at different time interval (30, 50, 75, 90 days after sowing/ transplanting (DAS/DAT), and at crop maturity) and, the DHA [11], acid and alkaline phosphatase activities were measured [12]. Statistical analysis was done for complete randomized design using WASP 2 [13].

\section{Results and Discussion}

\section{Acid Phosphatase Activity}

Data pertaining to acid phosphatase activities of soil was presented in Table 2. Variation in acid phosphatase enzyme activities was observed crop wise and at different crop growth periods. Among the crops, rice showed the highest mean acid phosphatase activity $(0.173 \mathrm{mg} \mathrm{PNP} / \mathrm{g} \mathrm{h})$ followed by finger millet $(0.165 \mathrm{mg} \mathrm{PNP} / \mathrm{g} \mathrm{h})$, pearl millet (0.154 mg PNP/g h), sorghum(0.140 mg PNP/g h), maize $(0.140 \mathrm{mg} \mathrm{PNP} / \mathrm{g} \mathrm{h})$ and soybean $(0.107 \mathrm{mg} \mathrm{PNP} / \mathrm{g} \mathrm{h})$. The acid phosphatase activity of soil varied in all the crops at different crop growth period. The maximum acid phosphatase activity was observed at 75 DAT for rice $(0.206 \mathrm{mg}$ $\mathrm{PNP} / \mathrm{g} \mathrm{h}), 90 \mathrm{DAS}$ for sorghum (0.194 $\mathrm{mg} \mathrm{PNP} / \mathrm{g} \mathrm{h}$ ) and pearl millet $(0.201 \mathrm{mg} \mathrm{PNP} / \mathrm{g} \mathrm{h}), 50 \mathrm{DAS}$ for soybean $(0.127 \mathrm{mg} \mathrm{PNP} / \mathrm{g} \mathrm{h})$, and 30 DAS for maize $(0.154 \mathrm{mg}$ $\mathrm{PNP} / \mathrm{g}$ h) and, $50 \mathrm{DAS}$ as well as 75 DAS for finger millet ( $0.180 \mathrm{mg} \mathrm{PNP} / \mathrm{g} \mathrm{h})$, respectively. Similar observations about the effect of different micro-organism on acid phosphates were observed in maize [9, 14]. Different crop growth stages showed different amount of acid phosphatase activity, it might be due to secretion of root exudates and biochemical changes in plant system [15]. Rice crop produce higher amount of root exudation in initial stages of crop growth which enhanced microbial activity in crop and modify nutrient concentrations in soil solution [16].

\section{Alkaline Phosphatase Activity}

The alkaline phosphatase activity of soil determined at different crop growth periods was presented in Table 3 .

Table 1 Varietal characteristics of crop cultivars used in the experiment

\begin{tabular}{lll}
\hline Crop & Varieties & Characteristics \\
\hline Sorghum & NJH-21 & $\begin{array}{c}\text { High yielding, drought tolerance, fatty acid composition 2.1-5.3\%, } \\
\text { total saturated fatty acid } 10.52 \% \\
\text { High yielding and early maturity; resistant to bacterial pastule, } \\
\text { bacterial blight and susceptible to yellow mosaic virus }\end{array}$ \\
Rice & JS-335 & $\begin{array}{c}\text { Also known as R-2022, having short bold grain with white colour. It is } \\
\text { best suited for irrigated areas }\end{array}$ \\
Maize & P-3540 & $\begin{array}{c}\text { Higher production, insect and acid resistant and suitable for rainfed } \\
\text { cultivation }\end{array}$ \\
Pearl millet & VBBH-3115 & $\begin{array}{c}\text { Highly resistant to downy mildew; more number of synchronous } \\
\text { tillers, long and very compact heads } \\
\text { Blast resistant, high production and total sugar reducing in reducing } \\
\text { form }\end{array}$ \\
\hline
\end{tabular}


Table 2 Effect of different crops on acid phosphatase activity (mg PNP/g h) in soil

\begin{tabular}{|c|c|c|c|c|c|c|}
\hline \multirow[t]{2}{*}{ Crop } & \multicolumn{5}{|c|}{ Crop growth period (DAS) } & \multirow[t]{2}{*}{ Mean } \\
\hline & 30 & 50 & 75 & 90 & At harvest & \\
\hline Sorghum & 0.138 & 0.118 & 0.145 & 0.194 & 0.106 & 0.140 \\
\hline Soybean & 0.108 & 0.127 & 0.101 & 0.097 & 0.103 & 0.107 \\
\hline Rice & 0.183 & 0.148 & 0.206 & 0.132 & 0.194 & 0.173 \\
\hline Maize & 0.154 & 0.132 & 0.140 & 0.133 & 0.143 & 0.140 \\
\hline Pearl millet & 0.139 & 0.159 & 0.159 & 0.201 & 0.110 & 0.154 \\
\hline Finger millet & 0.143 & 0.180 & 0.180 & 0.171 & 0.151 & 0.165 \\
\hline$C D(P=0.05)$ & 0.037 & 0.029 & 0.025 & 0.016 & 0.020 & \\
\hline
\end{tabular}

Table 3 Effect of different crops on alkaline phosphatase activity (mg PNP/g h) in soil

\begin{tabular}{|c|c|c|c|c|c|c|}
\hline \multirow[t]{2}{*}{ Crop } & \multicolumn{5}{|c|}{ Crop growth period (DAS) } & \multirow[t]{2}{*}{ Mean } \\
\hline & 30 & 50 & 75 & 90 & At harvest & \\
\hline Sorghum & 0.269 & 0.357 & 0.533 & 0.396 & 0.353 & 0.382 \\
\hline Soybean & 0.276 & 0.351 & 0.465 & 0.357 & 0.239 & 0.338 \\
\hline Rice & 0.214 & 0.370 & 0.440 & 0.309 & 0.294 & 0.325 \\
\hline Maize & 0.237 & 0.353 & 0.538 & 0.368 & 0.241 & 0.347 \\
\hline Pearl millet & 0.256 & 0.345 & 0.546 & 0.332 & 0.259 & 0.348 \\
\hline Finger millet & 0.245 & 0.264 & 0.530 & 0.450 & 0.235 & 0.345 \\
\hline$C D(P=0.05)$ & 0.024 & 0.062 & 0.060 & 0.056 & 0.051 & \\
\hline
\end{tabular}

Table 4 Effect of different crops on DHA ( $\mu \mathrm{g} \mathrm{TPF} / \mathrm{g} / 24 \mathrm{~h})$ in soil

\begin{tabular}{|c|c|c|c|c|c|c|}
\hline \multirow[t]{2}{*}{ Crop } & \multicolumn{5}{|c|}{ Crop growth period (DAS) } & \multirow[t]{2}{*}{ Mear } \\
\hline & 30 & 50 & 75 & 90 & At harvest & \\
\hline Sorghum & 34.11 & 34.46 & 38.35 & 37.56 & 34.27 & 35.75 \\
\hline Soybean & 31.40 & 30.47 & 35.63 & 32.05 & 35.03 & 32.92 \\
\hline Rice & 37.14 & 34.07 & 40.47 & 35.53 & 38.41 & 37.12 \\
\hline Maize & 31.62 & 26.35 & 33.62 & 30.20 & 29.11 & 30.18 \\
\hline Pearl Millet & 37.10 & 32.98 & 37.48 & 37.46 & 30.11 & 35.03 \\
\hline Finger Millet & 28.55 & 33.26 & 37.42 & 34.56 & 29.83 & 32.72 \\
\hline $\mathrm{CD}(P=0.05)$ & 2.27 & 2.76 & 2.73 & 0.84 & 1.25 & \\
\hline
\end{tabular}

From the values it was clear that alkaline phosphatase activity of soil increased up to 75 DAS and afterwards it declined in all the crops. In respect to crops, alkaline phosphatase activity in soil was maximum at 75 DAS in all the crops i.e. sorghum $(0.533 \mathrm{mg} \mathrm{PNP} / \mathrm{g} \mathrm{h})$, soybean $(0.465 \mathrm{mg} \mathrm{PNP} / \mathrm{g} \mathrm{h})$, rice $(0.440 \mathrm{mg} \mathrm{PNP} / \mathrm{g} \mathrm{h})$, maize $(0.538 \mathrm{mg} \mathrm{PNP} / \mathrm{g} \mathrm{h})$, pearl millet $(0.546 \mathrm{mg} \mathrm{PNP} / \mathrm{g} \mathrm{h})$ and finger millet $(0.530 \mathrm{mg} \mathrm{PNP} / \mathrm{g} \mathrm{h})$, respectively. The mean alkaline phosphatase activity of soil was highest in sorghum $(0.382 \mathrm{mg} \mathrm{PNP} / \mathrm{g} \mathrm{h})$ followed by pearl millet (0.348 mg PNP/g h), maize $(0.347 \mathrm{mg} \mathrm{PNP} / \mathrm{g} \mathrm{h})$, finger millet $(0.345 \mathrm{mg} \mathrm{PNP} / \mathrm{g} \mathrm{h})$, soybean $(0.338 \mathrm{mg} \mathrm{PNP} / \mathrm{g} \mathrm{h})$ and rice $(0.325 \mathrm{mg} \mathrm{PNP} / \mathrm{g} \mathrm{h})$ respectively. Vigorous crop growth enhanced the root exudation in soil and it enhanced the biological activities in the rhizosphere, which directly and indirectly enhanced the enzyme activity in soil [8].

Dehydrogenase Activity

Effect of different crops on DHA in soil was enlisted in Table 4. Among the enzymes DHA showed the little bit different path during the study. It varied from 34.11 to $38.35 \mu \mathrm{g} \quad \mathrm{TPF} / \mathrm{g} / 24 \mathrm{~h}, \quad 30.47-35.63 \mu \mathrm{g} \quad \mathrm{TPF} / \mathrm{g} / 24 \mathrm{~h}$, 34.07-40.47 $\mu \mathrm{g}$ TPF/g/24 h, 26.35-33.62 $\mu \mathrm{g}$ TPF/g/24 h, 30.11-37.48 $\mu \mathrm{g}$ TPF/g/24 h and 28.55-37.42 $\mu \mathrm{g}$ TPF/g/ $24 \mathrm{~h}$ in sorghum, soybean, rice, maize, pearl millet and 
finger millet, respectively. But DHA activity varied crop wise and different crop growth period, the maximum activity was found at 75 DAS in all the crops, sorghum (38.35 $\mu \mathrm{g} \mathrm{TPF} / \mathrm{g} / 24 \mathrm{~h})$, soybean $(35.63 \mu \mathrm{g} \mathrm{TPF} / \mathrm{g} / 24 \mathrm{~h})$, rice $(40.47 \mu \mathrm{g} \mathrm{TPF} / \mathrm{g} / 24 \mathrm{~h})$, maize $(33.62 \mu \mathrm{g} \mathrm{TPF} / \mathrm{g} / 24 \mathrm{~h})$, pearl millet $(37.48 \mu \mathrm{g} \mathrm{TPF} / \mathrm{g} / 24 \mathrm{~h})$, and finger millet (37.42 $\mu \mathrm{g} \mathrm{TPF} / \mathrm{g} / 24 \mathrm{~h}$ ). It might be due to vigorous growth of the crops at $75 \mathrm{DAS}$, and the root exudation also more in this period. More microbial activities increased the DHA in the rhizosphere, due to more availability of food materials for its growth [17]. Variation in DHA activity in the rhizosphere due to plant genetic as well microbial species associated with it [18].

\section{Conclusion}

It was concluded that the kharif crops play a vital role in Indian food grain production but the cost of production is increasing due to fertilizers especially phosphorus. It reduces the profit of farmers. Different crops having rhizosphere effect on nutrient availability. Experimental data showed that various crops rhizosphere produced a different level of acid phosphatase activity. The highest acid phosphatase activity was observed at different stages for different crops, but alkaline phosphatase and dehydrogenase activities were maximum at 75 DAS in all the crops. These enzyme activities associated with higher availability and uptake of nutrients particularly phosphorus in plants.

Open Access This article is distributed under the terms of the Creative Commons Attribution License which permits any use, distribution, and reproduction in any medium, provided the original author(s) and the source are credited.

\section{References}

1. Gull M, Hafeez FE, Saleem M, Malik KA (2004) Phosphorus uptake and growth promotion of chickpea by co-inoculation of mineral phosphate solubilizing bacteria and a mixed rhizobial culture. Aust J Exp Agric 44:623-628

2. Dotaniya ML, Datta SC, Biswas DR, Meena BP (2013) Effect of solution phosphorus concentration on the exudation of oxalate ions by wheat (Triticum aestivum L.). Proc Natl Acad Sci Ind Sect B 83(3):305-309
3. Abolfazli F, Forghani A, Norouzi M (2012) Effects of phosphorus and organic fertilizers on phosphorus fractions in submerged soil. J Soil Sci Plant Nutr 12(2):349-362

4. Veneklaas EJ, Lambers H, Bragg J, Finnegan PM, Lovelock CE, Plaxton WC, Price CA, Scheible WR, Shane MW, White PJ, Raven JA (2012) Opportunities for improving phosphorus-use efficiency in crop plants. New Phytol 195:306-320

5. Vashista P, Choudhary N, Sharma CB (2006) Plant protein tyrosine phosphatases: an overview. Proc Natl Acad Sci 76(3):207-215

6. Bais HP, Weir TL, Perry LG, Gilroy S, Vivanco JM (2006) The role of root exudates in rhizosphere interactions with plants and other organisms. Annu Rev Plant Biol 57:233-266

7. Alk PDB, Kim EE, Wyckoff HW (1991) Reaction mechanism of alkaline phosphatase based on crystal structures two metal ion catalysis. J Mol Biol 218(2):449-464

8. Vega NWO (2007) A review on beneficial effects of rhizosphere bacteria on soil nutrient availability and plant nutrient uptake. Rev Fac Nal Agr Medellín 60(1):3621-3643

9. Alam S, Khalil S, Ayub N, Rashid M (2002) In vitro solubilization of inorganic phosphate by phosphate solubilizing microorganism (PSM) from maize rhizosphere. Intl J Agric Biol $4: 454-458$

10. Chen J (2006) The combined use of chemical and organic fertilizer and or biofertilizer for crop growth and soil fertility. In: International workshop on sustained management of the soilrhizosphere system for efficient crop production and fertilizer use, Thailand, 16-20

11. Casida LE, Klein DA, Santoro T (1964) Soil dehydrogenase activity. Soil Sci 98:371-376

12. Tabatabai MA, Bremner JM (1969) Use of p-nitrophenyl phosphate for assay of phosphatase activity. Soil Bio Biochem $1: 301-307$

13. Gomez KA, Gomez A (1983) Statistical procedures for agricultural research, 2nd edn. Wiley, New York

14. Baudoin E, Benizri E, Guckert A (2002) Impact of growth stages on bacterial community structure along maize roots by metabolic and genetic finger printing. Appl Soil Ecol 19:135-145

15. Sugiyama A, Yazaki K (2012) Root exudates of legume plants and their involvement in interactions with soil microbes. In: Vivanco JM, Baluska F (eds) Secretions and exudates in biological systems, signaling and communication in plants. Springer, Heidelberg, pp 27-48

16. Dotaniya ML (2012) Crop residue management in rice-wheat cropping system. Lap Lambert Academic Publisher, Saarbrucken, p 116

17. Nihorimbere V, Ongena M, Smargiassi M, Thonart P (2011) Beneficial effect of the rhizosphere microbial community for plant growth and health. Biotechnol Agron Soc Environ 15(2):327-337

18. Das BB, Dkhar MS (2011) Rhizosphere microbial populations and physico chemical properties as affected by organic and inorganic farming practices. Am Eur J Agric Environ Sci 10(2):140-150 